\title{
TIME-VARYING INTEGRATION IN EUROPEAN GOVERNMENT BOND MARKETS.*
}

\author{
Pilar Abad ${ }^{a}$ Helena Chuliáb and Marta Gómez-Puig ${ }^{c}$ \\ April 2011
}

\begin{abstract}
Bond market integration clearly changes in response to economic and financial conditions, since the level of risk aversion changes and investors require time-varying compensation for accepting a risky payoff from financial assets. In this paper we examine the dynamic behavior of European Government bond market integration using an asset pricing model based on that of Bekaert and Harvey (1995). Our sample period begins in 2004, after a period of calm and tranquility, and ends in 2009 , with a significant widening of sovereign bond spreads. Our results show evidence of timevarying level of integration for all European countries and suggest that, from the beginning of the financial market tensions in August 2007, markets moved towards higher segmentation, and the differentiation of country risk factors increased substantially across countries. However, the impact of the financial and economic crisis has been much more harmful for EMU members' sovereign bond markets, since it has prompted an important backward step in their integration process.
\end{abstract}

JEL Classification: E44, F36, G15.

Keywords: Monetary union, sovereign securities markets, bond market integration.

\footnotetext{
* aPilar Abad: University Rey Juan Carlos \& RFA-IREA. bHelena Chuliá: University of Barcelona \& RFA-IREA. cMarta Gómez-Puig: University of Barcelona \& RFA-IREA. Pilar Abad and Helena Chuliá acknowledge financial support from Fundación Ramon Areces. This paper is based upon work supported by the Government of Spain and FEDER under grant number ECO2010-21787-C03-01, ECO2008-02752/ECON and ECO2009-14457-C04-04. Corresponding author: Marta Gómez-Puig, Department of Economic Theory, University of Barcelona. Av. Diagonal 690. Barcelona 08034. Spain. T: 34-934.021.933. E-mail: marta.gomezpuig@ub.edu
} 


\section{Introduction}

Since the introduction of the single currency, euro area monetary policy authorities have had a keen interest in the integration and efficient functioning of the financial system in Europe, especially in European and Monetary Union (EMU) countries. Indeed, financial integration is of key importance for the application of the single monetary policy and for financial stability, and improves access to financial markets (see European Central Bank, 2010). However, it is worth noting that a high degree of financial integration may decrease the opportunity for risk diversification and raise the likelihood of spillover effects and contagion, as the sovereign debt crisis in the Eurozone has revealed.

In this paper, we will continue the analysis presented in Abad, Chuliá and Gómez-Puig (2010, ACGP 2010 hereafter) and focus our attention on bond market integration in the European Union (EU). The main objective of our previous paper was to study whether the introduction of the euro had had an impact on the degree of integration of EU-15 government bond markets. Since the extent to which integration has progressed in the EU bond market can be assessed by measuring the relative importance of country components versus other factors in explaining bond returns, we applied a CAPM based model and separated each individual country's government bond return into two effects: a local (own country), and a systemic effect (either a regional/Eurozone or a global/world effect). It is intuitive that as integration advances, the proportion of the total return explained by local effects should decrease. Our results presented evidence that during the first ten years after its introduction, the euro had a major impact on the degree of integration of European government bond markets. The main conclusions of our analysis were, on the one hand, that markets of countries which shared a monetary policy were less vulnerable to the influences of world risk factors and more vulnerable to EMU risk factors and, on the other, that Eurozone markets were only partially integrated with the German market. The proportion of the total return explained by country effects was still important and investors were able to benefit from portfolio risk diversification. 
An important restriction of the ACGP (2010) analysis was that, for each country, we estimated "the average level" of integration with the US and the German bond markets during the ten year period (1999-2008) and disregarded the fact that bond market integration changes over time. Nevertheless, the financial market tensions that started in August 2007 and were followed by a global financial and economic crisis led to significantly rising yield spreads in European government bond markets along with increased differentiation of country risk across the Eurozone. This situation highlighted the fact that bond market integration clearly changes in response to economic and financial conditions, since the level of risk aversion changes and investors require time-varying compensation for accepting a risky payoff from financial assets. For this reason, some studies have allowed integration to vary over time and with events (see Bekaert and Harvey, 1995, or Hardouvelis et al. 2006 among them).

This paper aims to address this question and to provide empirical evidence on the "dynamic nature of bond market integration" among EU-15 (euro and non-euro participants) and three economies from the central and eastern European (CEE) group of countries which became member States of the European Union in 2004, even though they have not yet adopted the euro: Poland, Hungary and the Czech Republic. These economies were chosen because they are the largest amongst the new incoming members and, compared to their neighbors, are large issuers of sovereign debt. In fact, among the new EU members, they have the largest and most liquid government debt markets.

Although little has been written on the sources of co-movements in government bond markets in the EU-15 context (studies of this issue include ACGP, 2010, Geyer, Kossmeier and Pischer, 2004, Gómez-Puig, 2009a and 2009b, and Pagano and Von Thadden, 2004), literature on the new EU members (Gardó and Martin, 2010, Kim et al., 2006 or Nickel et al., 2009) is even scarcer. Therefore, whilst there is some evidence of the degree of integration of bond markets within the EU-15, much less is known about the level and dynamics of financial integration within the new EU members. However, it is worth noting that, at varying speeds, these countries are being

\footnotetext{
${ }^{1}$ With the exception of Luxembourg, due to the fact that its debt market is negligible.
} 
integrated in the world economy and international financial markets. According to some indicators, they still present the characteristics of emerging economies, but according to others (especially the more forward-looking ones) they should be classified as developed economies.

In this paper we will analyze the time-varying degree of integration of four different groups of European sovereign debt markets with the German one: (1) Non-EMU new EU (the Czech Republic, Hungary and Poland), (2) non-EMU EU-15 (Denmark, Sweden and UK), (3) EMU EU15 peripheral (Greece, Ireland, Italy, Portugal and Spain), and (4) EMU EU-15 central bond markets (Austria, Belgium, Finland, France and the Netherlands).

Because of the choice of the countries in our sample, our analysis covers the period from January 2004, when Poland, the Czech Republic and Hungary joined the European Union, and November 2009. This finishing date is chosen in order to avoid the influence of the start of the huge sovereign debt crisis in Europe. We honestly think that it is better to omit data corresponding to 2010 from the study because the recent sovereign debt crisis deserves independent analysis, since it may have been spurred not only by macroeconomic and fiscal risk perception but also by speculation regarding the survival of the euro. On the other hand, the omission of the 1999-2003 period from our study will not substantially affect the results, since after the introduction of the euro in January 1999 and until the subprime crisis in global financial markets in August 2007, spreads on bonds of Eurozone members had moved in a narrow range with only slight differentiation across countries (see Figure 1). In fact, the stability and convergence of spreads was considered a hallmark of successful financial integration within the Eurozone.

Nevertheless, after the subprime crisis in 2007 severe tensions emerged in financial markets worldwide including the Eurozone bond market. Following the collapse of the US financial institution Lehman Brothers on 15 September 2008, the period of financial turmoil turned into a global financial crisis that began to spread to the real sector, with a rapid, synchronized deterioration in economic conditions in most major economies. At the same time the financial crisis 
showed that imbalances within the Eurozone still persist since interest rate differentials between government bond issues of participating countries, which had reached levels close to zero between 2003 and 2007, now reemerged. In fact, risk premia on EMU government bonds which had followed a secular downward trend in the past (Figure 1) increased strongly in 2008, reflecting investor perceptions of upcoming macroeconomic and fiscal risks².

In this scenario, the aim of this paper is to study the dynamic behavior of bond market integration with the Eurozone bond market, which is proxied by the German market, in the 16 EU countries mentioned above: 13 EU-15 countries jointly with Poland, Hungary and the Czech Republic, during a timespan beginning after a period of calm and tranquility in EMU markets and ending with a significant widening of sovereign bond spreads. In order to analyze the dynamic nature of integration we use an asset pricing model based on that of Bekaert and Harvey (1995) and consider that the time-varying coefficient that captures the degree of integration with the Eurozone market is dependent on a set of domestic economic instruments relative to Germany.

We find evidence of a time-varying level of integration, which decreases in all countries as the financial market tensions which started in August 2007 developed into a global financial and economic crisis. Our results suggest that the relative importance of country components versus other factors in explaining bond returns, and consequently bond market segmentation, increased with the deterioration of the economic situation in Europe which has accentuated imbalances across economies.

The time-series pattern of the degree of integration presents similar trends across our four categories of countries, but the impact of the financial and economic crisis clearly differs between groups and within countries in the same group. After September 2008, the non-EMU EU-15 and the EMU peripheral groups are the ones whose bond markets present the highest drop in their degree of integration with the German one. However, whilst the dispersion of the time-varying

2 Borri et al. (2010) present a model in which bond prices depend not only on borrowers' economic conditions, but also on lenders' time-varying risk-aversion. 
degree of integration remains relatively stable in non-EMU countries, it records an average decrease of $178 \%$ in the case of EMU peripheral countries, reflecting clear differences in the dynamic behaviour of integration between these countries.

These results suggest that the impact of the financial and economic crisis has been much more harmful for EMU members' sovereign bond markets, since it has prompted an important backward step in their integration process.

The remainder of the paper is organized as follows. Section 2 lays out the methodology we use to estimate time-varying integration. Section 3 describes the bond market data and the instruments for the price of risk and the time-varying integration parameter. Section 4 discusses the empirical results. Finally, Section 5 concludes.

\section{Model}

Following Hardovelius et al. (2006), who analyse European stock market integration, our model builds on Bekaert and Harvey (1995)'s CAPM-based model and assumes that excess returns in country $i$ are generated by the following version of the conditional international CAPM:

$r_{i, t}=\theta_{i, t} \lambda_{E, t} \operatorname{cov}_{t-1}\left(\mathbf{r}_{E, t,} \mathbf{r}_{i, t}\right)+\left(1-\theta_{i, t}\right) \lambda_{i, t} \operatorname{var}_{t-1}\left(\mathbf{r}_{i, t}\right)+e_{i, t}$

where $r_{i, t}$ is the excess return on the local bond market, $r_{E, t,}$ is the excess return on the Eurozone bond market, $\operatorname{cov}_{t-1}$ is the conditional covariance operator, $\operatorname{var}_{t-1}$ is the conditional variance operator, $\lambda_{E, t}$ is the Eurozone price of risk, and $\lambda_{i, t}$ is the local price of risk. The time-varying parameter $\boldsymbol{\theta}_{\boldsymbol{i}, \boldsymbol{t}}$ is interpreted as a measure of the conditional level of integration of market $i$ with the Eurozone bond market. When markets are completely integrated the coefficient $\boldsymbol{\theta}_{i, t}$ takes the value 1, thus the variance term in Equation (1) is reduced to zero and only covariance with the Eurozone bond market is priced. If $\boldsymbol{\theta}_{i, t}$ takes the value zero, only the variance is priced. 
The time-varying parameter $\boldsymbol{\theta}_{\boldsymbol{i}, t}$ is conditioned on a set of variables that measure integration: $\theta_{i, t}=\exp \left(-\left|g_{i}^{\prime} X_{i, t}\right|\right)$

where $g_{i}$ is a vector of country-specific parameters (including a constant), and $X_{i, t}$ is a vector of country-specific predetermined information variables related to convergence toward EMU. We take the absolute value of $g_{i}^{\prime} X_{i, t}$ Thus, we assume that deviations of the information variables from zero, independent of their sign, reduce the degree of integration. By construction $\theta_{i, t}$ takes a value between zero and unity.

The excess return on the Eurozone portfolio Government's bonds is modelled similarly as:

$r_{E, t}=\lambda_{E, t} \operatorname{var}_{t-1}\left(\mathbf{r}_{E, t}\right)+e_{E, t}$

To model the conditional covariance matrix we use a multivariate GARCH model, the BEKK model proposed by Engle and Kroner (1995). This model can be written as:

$\mathrm{H}_{t}=\mathrm{C}^{\prime} \mathrm{C}+\mathrm{A}^{\prime} \boldsymbol{e}_{t-1} \boldsymbol{e}^{\prime}{ }_{t-1} \mathrm{~A}+\mathrm{B}^{\prime} \mathrm{H}_{t-1} \mathrm{~B}$

where $\mathbf{C}$ is a $(N \mathrm{x} N)$ symmetric matrix and $\mathrm{A}$ and $\mathrm{B}$ are diagonal $\left(N_{\mathrm{x}} N\right)$ matrices of constant coefficients. By doing this, we allow the variances to depend only on lagged squared errors and lagged conditional variances and the covariances to depend only upon cross-products of lagged errors and lagged conditional covariances (see Bollerslev et al. (1988) and De Santis and Gerard $(1997,1998))$.

Finally, following the financial literature (see Bekaert and Harvey, 1995 and De Santis and Gerard, 1997, among others), we model the price of risk as a function of a set of information variables. As the price of risk must be positive (see Merton, 1980), the functional form that we assume is:

$\lambda_{\mathrm{E}, t}=\exp \left(\mathrm{K}_{\mathrm{E}} \mathrm{Z}^{\mathrm{E}} t\right)$ 
where $Z^{E}$ represents Eurozone variables, $Z^{L}{ }_{i}$, represents local variables for country $i$, and $\mathrm{K}_{\mathrm{E}}$ and $\delta^{\prime}{ }_{i}$ are vectors of coefficients.

We estimate a system of equations using the Quasi-Maximum Likelihood method. Bollerslev and Wooldridge (1992) show that the standard errors calculated using this method are robust even when the normality assumption is violated. Then, for each local government bond market we estimate a system of 6 equations, (1) to (6). This estimation is implemented in two steps. First, we estimate a univariate model of the Eurozone bond market return (equation 3) and the relevant variance-covariance elements of equation (4). Then we impose the results on the individual countries in $N$ bivariate regressions. Thus, we restrict the estimates of the Eurozone government bond market price of risk and of the coefficients in the conditional variance of the Eurozone market to be the same in all countries. Once these estimates are imposed on each bivariate regression, in the second step we will obtain the following for each country: $\boldsymbol{\theta}_{\boldsymbol{i}, \boldsymbol{t}}$ (the estimated conditional level of integration with the Eurozone bond market), $K_{E}$ (the vector of estimated coefficients for the Eurozone price of risk) and $\delta_{i}$ (the vector of estimated coefficients for the local price of risk). ${ }^{3}$

\section{Data}

\subsection{Returns}

The empirical analysis uses the 10-year JPMorgan Government Global Bond Index (JPMGBI), in terms of a common currency, the euro, and the sample includes 16 European countries. Our study focuses on 10 EMU EU-15 (Austria, Belgium, France, Greece, Ireland, Italy, Finland, the Netherlands, Portugal and Spain) and 6 non-EMU countries (Denmark, Czech Republic, Hungary, Poland, Sweden and UK). Data have been collected from Thompson Datastream. We use daily

\footnotetext{
3 According to Bekaert and Harvey (1995), this procedure imposes the restriction that the price of Eurozone market risk is the same in each country, which leads to more powerful tests. A disadvantage of this approach is that the usual standard errors are likely to be understated since we ignore the sampling error in the first-stage parameter estimates.
} 
data ${ }^{4}$ covering the period from January 2004 to November 2009, except for two new EU countries: the Czech Republic and Hungary, where the start date is November 2004. Returns are calculated as first $\log$ differences.

The dependent variable in our model $\left(r_{i t}\right)$ is the excess return which is calculated relative to the appropriate 1-month Euro-deposit offered rate quoted in London 5 . In our analyses, we use the German government bond index as the proxy for the entire Eurozone given that it has a correlation of 0.99 with the JP Morgan EMU government index (over the same sample period) which can also be obtained from Thompson Datastream. We think that this is a better way to capture regional risk effect than using the return of a synthetic Eurozone bond index which will always contain the evolution of the own local market return.

\subsection{Instruments for the Price of Risk}

Like ACGP (2010), we use the following instrumental variables to capture the different prices of risk (Eurozone and local risk): (1) the slope of the yield curve, as measured by the difference between the 10-year and the 3-year government bond returns. Several studies (Campbell and Shiller, 1991; Ilmanen, 1996) have found that steeper yield curves are associated with higher subsequent yields on longer-maturity bonds. The interpretation of this finding is that the yield curve steepens primarily because of an increase in the risk premium. Moreover, the slope of the yield curve is also a proxy of the business cycle. (2) Lagged stock indexes returns are included to allow for the possibility that stock returns lead bond returns. In recent years, important cross-asset linkages between stocks, bonds and money market instruments have been observed. Fleming, Kirby and Ostdiek (1998) investigate the nature of volatility linkages between stocks, bonds and money markets and conclude that volatility linkages between the three markets are strong. In particular, stock market weakness has been associated with economic weakness, which has corresponded to bond market strength ${ }^{6}$. If equity market weakness gives rise to subsequent bond market strength, the coefficient on lagged stock

\footnotetext{
${ }^{4}$ Bond markets for the countries under consideration are approximately open for the same hours during the day.

${ }^{5}$ Euro-deposit rates are used as a proxy for the risk free rate due to the lack of a liquid Treasury bill market in some of the countries.

${ }^{6} \mathrm{Kim}$ et al. (2006) present evidence that the introduction of the monetary union has Granger-caused an apparent segmentation between bond and stock markets within Europe. Hence, the EMU has increased the benefits of diversification across stocks and government bonds at the country level.
} 
indexes returns should be significantly negative (see Hunter and Simon, 2005).7 (3) Lagged 10-year Government returns are also added to the specification. Taking into account that some aspects of risk premiums (related to domestic factors such as liquidity or credit risk) do not change over the period considered, the objective will be to identify their relative importance in explaining fluctuations, rather than returns levels. With this aim, a lag of the dependent variable is introduced in the model, which will allow for a slow dynamic adjustment to a long-term equilibrium value of government returns. Finally, (4) we include the difference between lagged 10-year government returns and lagged stock index returns to capture bond market relative risk compared to that of stock markets.

Since we use German returns as proxies of the Eurozone, the following Eurozone instruments are applied: (1) the slope of the German yield curve, as measured by the difference between the 10-year and the 3-year German government bond return. (2) The lagged return of the DAX-30. We think that the use of this index is appropriate as it reflects the price evolution of the 30 most important firms in the German stock market. (3) The lagged value of the 10-year German government return and (4) The difference between lagged 10-year German government return and lagged DAX-30 return.

Table 1 records the results obtained by regressing the excess returns of the 16 local markets on both the local and the Eurozone instruments, as follows:

$r_{i, t}=a_{i}+b E_{i} Z_{t-1}+b{ }_{i} Z_{i} L_{i,-1}+\varepsilon_{i, t}$

where for every country $i$, we assume that government bond excess returns $\left(r_{i, t}\right)$ are linearly related to Eurozone $\left(Z^{E}\right)$ and local $\left(Z^{L_{i}}\right)$ information variables. We estimate this equation by OLS to identify the relevant instruments. Furthermore, we test the separate hypothesis that the coefficients associated with the Eurozone and local variables are zero.

\footnotetext{
7 Nevertheless, note that other authors (see McQueen and Roley (1993)) demonstrate that the opposite results are obtained when market participants are concerned about an overheating economy. During these periods, data suggesting a weaker-than-expected economy lead to stronger bond and stock prices as this makes it less likely that the Federal Reserve will be forced to tighten monetary policy aggressively and possibly drive the economy into a recession.
} 
The R2s range from $49 \%$ in Sweden to $91 \%$ in France or Spain, indicating a high degree of predictability in local bond markets. The F-tests reveal that each set of instruments is separately and jointly significant. For all countries, we reject the null hypothesis that local instruments can be excluded. We also reject the null hypothesis that Eurozone instruments can be excluded at the $10 \%$ significance level with the exceptions of France and Hungary.

Then, we estimate equation (7) using the local and Eurozone instruments separately. The results show clear patterns of predictability in all local bond markets using local instruments. We observe that when we only use local instruments the R2s are similar to when we use all instruments, whilst when we only use Eurozone instruments the R2s are lower. Thus, the predictability power of local instruments is higher than that of regional instruments in all countries. Moreover, in some countries (Czech Republic, Finland and Hungary) the usefulness of regional instruments is substantially reduced, although the F-tests reveal that both sets of instruments are significant. Overall, the results show that a set of Eurozone and local instruments are useful to predict local bond returns, suggesting incomplete integration.

\subsection{Instruments for the Time-Varying Integration Parameter}

In our model, each country has its own time-varying degree of integration. The degree of integration is conditioned on a set of domestic economic instruments relative to Germany: (1) The inflation differential, (2) the industrial production index rate of the growth differential and (3) the debt-to-GDP rate of the growth differentials. The use of domestic indicators to explain the behavior of the time-varying degree of integration is justified on the grounds that external imbalances necessarily have internal counterparts9.

In particular, the inflation differential and the industrial production index rate of the growth differential (a proxy of the business cycle) relative to Germany are included to take account of the

\footnotetext{
${ }^{8}$ Reinhart and Rogoff (2010) present empirical evidence about the relationship between debt levels, growth and inflation.

${ }^{9}$ See European Commission (2010).
} 
argument put forward by Mody (2009) and Alfonso (2010) that countries' sensitivity to the financial crisis is more pronounced the greater the loss of competitiveness and growth potential.

On the other hand, as Mody (2009) points out, after the failure of Lehman Brothers countries with higher debt levels faced more stress on their debt servicing capabilities and, hence, were penalized more as a consequence of the substantial reevaluation of global growth prospects. Actually, an important point that Reinhart and Rogoff (2008) make is that the eventual rise in public debt is only partly due to the direct costs of rescuing distressed financial institutions: the bulk of the rise in the public debt-to-GDP ratio reflects the slowdown in growth associated with the banking/economic crisis. This is also likely to be the case for the ongoing crisis, which has revealed a rising influence of the loss of competitiveness and slowdown in growth on the rise in the public debt-to-GDP ratio and government yield spreads. However, there are statistical challenges in identifying the relationship between public debt and the high-frequency changes in spreads (see Pagano and von Thadden, 2004). This is the reason why we will use a flow instead of a stock variable in our study. Specifically, the relative rate of growth of debt-to-GDP ratios will be the instrument that we will include to study the time-varying degree of integration with the German bond market.

All the variables that have been used to build up the instruments (the Harmonized Index of Consumer Prices, the Production Index ${ }^{10}$, Government debt and the GDP) have been compiled from Eurostat. Daily data have been linearly interpolated from monthly and quarterly observations.

\section{Results}

Table 2 presents the results of the estimation of the system of equations (1) to (6) using the QuasiMaximum Likelihood method for each of the local government bond markets jointly with the German government bond market. Table 3 shows the standardized residuals analyses. It can be observed (with few exceptions) that the standardized residuals appear free from serial correlation

\footnotetext{
${ }^{10}$ We have used the seasonally adjusted production index.
} 
and heteroskedasticity. In all cases, the necessary conditions for the stationarity of the process are satisfied.

Most of the Eurozone and local instruments are significant, suggesting that they are relevant in forecasting the Eurozone and local price of risk. All the coefficients in the (co)variance equations (not reported) are significant, confirming the existence of time-varying volatilities.

The estimates of the instruments for the time-varying integration parameter displayed in the last four columns of Table 2 indicate that our instruments are important determinants of bond market integration. Both the industrial production and the debt-to-GDP growth differential are statistically significant in all countries, whilst the inflation differential is significant in 12 out of 16 cases.

To simplify the interpretation of the results, Table 4 shows the average level of integration for the total sample period and three sub-sample periods: (1) From 4 January 2004 to 8 August 2007, (2) from the beginning of the subprime crisis on 9 August 2007 to 14 September 2008 and (3) from the collapse of Lehman Brothers on 15 September 2008 to 30 November 2009. We have divided the total period into these subsamples because between the introduction of the euro in January 1999 and the subprime crisis in global financial markets in August 2007, spreads on bonds of Eurozone members had moved in a narrow range with only modest differentiation across countries. However, the financial market tensions which started in August 2007 and were followed by a global financial and economic crisis after the collapse of Lehman Brothers in September 2008 led to significantly rising yield spreads in European government bond markets (see Figure 1). Therefore, the timevarying degree of integration with the German market should have decreased after these episodes of financial turbulence.

Thus, our aim is to analyze whether these episodes of financial crisis have had different impacts in the degree of integration of European sovereign bond markets with the German one. As explained above, in our analysis we have divided European markets into four different groups: (1) Non-EMU 
new EU (Czech Republic, Hungary and Poland), (2) non-EMU EU-15 (Denmark, Sweden and UK), (3) EMU EU-15 peripheral (Greece, Ireland, Italy, Portugal and Spain), and (4) EMU EU-15 central bond markets (Austria, Belgium, Finland, France and the Netherlands).

To test the equality of means of the level of integration in the three sub-sample periods, we carried out an ANOVA test with different null hypothesis. First we tested the null hypothesis that the mean of the level of integration is the same before the beginning of the subprime crisis and after it; second, we tested the null hypothesis that the mean of the level of integration is equal in the second and third sub-periods, and finally, the joint test with the null hypothesis that the mean of the level of integration is equal in the three sub-samples. In all cases, the results of the test (not reported) reject the null hypothesis, indicating that the means of the level of integration in the different subperiods are statistically different.

Table 4 shows that, as expected, the level of integration with the German market is higher in EMU than in non-EMU countries. Within non-EMU countries, the average level of integration throughout the period of the new EU countries (0.30) is slightly lower than that of the non-EMU EU-15 countries (0.36). Within EMU countries, it is worth noting that, on average, peripheral countries also present a level of integration (0.51) which is lower than that of the central countries (0.60): Greece, Ireland and Portugal are the Eurozone countries with the lowest degree of integration whilst the Netherlands and France are the ones with the highest level (the average level of integration is 0.37 in the case of the Greek market and 0.70 in the case of the French one).

However, as displayed in Figures 2a to 2d, which show time-varying integration of bond markets grouped in the different categories, the impact of the financial and economic crisis clearly differs between groups and within countries in the same group. First, the time-series pattern of the degree of integration is similar across new EU-15 members (Figure 2a) until 9 August 2007 but the subprime crisis and the failure of Lehman Brothers do not have the same impact in these countries. In the case of the Czech Republic the level of integration begins to decrease with the subprime 
crisis, coinciding with a sharp increase in the country's inflation rate and a worsening of its growth potential (measured by the production index). In contrast, in Poland and Hungary the level of integration remains stable until the collapse of Lehman Brothers and decreases after it. In this respect, it is worth noting that Poland is the country with the highest loss of competitiveness and Hungary presents the largest deterioration in its production growth relative to Germany at the end of the sample period. The results for these countries also suggest that these markets are more segmented than integrated with Germany: the degree of integration never exceeds 0.30 at any point during the sample period. On the other hand, Table 5 shows that the dispersion within countries of the time-varying degree of integration increases at the end of the sample period, coinciding with the beginning of the financial turbulence in August 2007, which supports the idea that its dynamic behavior differs within countries ${ }^{11}$.

Second, Figure $2 \mathrm{~b}$ shows that the level of integration of non-EMU EU-15 countries follows a similar pattern. The level of integration is stable around 0.40 until 15 August 2008 and after this date markets move towards a higher segmentation coinciding with the collapse of Lehman Brothers. On average, this group of countries registers the highest fall in the degree of integration $(42 \%)$. This fall is most pronounced in the case of Denmark and the UK, the countries in this group with the highest rise in the rate of growth of their debt-to-GDP and the greatest loss of competitiveness (measured by the inflation differential) relative to Germany in the studied period. Moreover, it is noticeable that, in contrast to the former group of countries, the dispersion within countries of the time-varying degree of integration decreases coinciding with the subprime crisis, just to increase again with the fall of Lehman Brothers (see Table 5). It is worth noting that the degree of integration of countries in this group follows a similar dynamic pattern (the average value of the coefficient of variation presents the lowest value in this subsample), even though these countries do not belong formally to any group.

\footnotetext{
${ }^{11}$ Table 5 shows the average of the daily coefficient of variation of the time-varying degree of integration for the four groups of countries which correspond to figures $2 \mathrm{a}-2 \mathrm{~d}$.
} 
Regarding EMU EU-15 countries, as explained above, we differentiate between peripheral and central countries. In the case of peripheral countries (see Figure 2c), it is noticeable that, after the collapse of Lehman Brothers, not only does the level of integration record a significant decrease (28\% on average), but also its dispersion across countries rises substantially (the coefficient of variation registers an average increase of around $178 \%$, see Table 5), suggesting a move towards a higher differentiation of idiosyncratic and local risk factors in these countries since the financial crisis. Ireland, Greece and Spain are the countries whose bond markets present the highest drop in their degree of integration with the German one $(67 \%, 36 \%$ and $28 \%$, respectively). In the case of Ireland and Spain this decrease coincides with a significant rise in their public debt-to-GDP growth relative to Germany.

Conversely, as Figure 2d shows, in the case of EMU central countries, all bond markets (with the exception of Finland and France) follow a similar pattern up until the subprime crisis, when their level of integration drops sharply until the end of 2008 , followed by another upward trend until the end of the sample period together with an increase in the dispersion within countries (see Table 5).

Overall, our results reveal a clear decrease in the level of integration over the sample period for most of the countries, suggesting that, once the financial market tensions that started in August 2007 turned into a global financial and economic crisis, the differentiation of country risk factors increased substantially across EU countries. Actually, one of the consequences of the global financial crisis is that it has stressed the relevance of domestic imbalances and local risk factors in explaining bond returns, which were probably not accurately priced by agents during the period of stability that preceded it. As a consequence, the negative impact of the crisis has been higher in the group of countries that had achieved a higher degree of integration before it started. This is the case of EMU countries (in particular, peripheral countries) whose bond markets, after a large period of convergence with the German market, have found their integration process seriously affected. 
To conclude, since the relative importance of country components versus other factors in explaining bond returns rises with the deterioration of the economic situation (the impact of which differs across European countries) the dynamic CAPM based model we have applied in the analysis seems to be suitable for examining the time-varying degree of integration of European government bond markets.

\section{Conclusions}

The financial turmoil of 2007 and 2008 affected the sovereign bond markets in different European countries in very different ways. One consequence was a significant rise in yield spreads, along with an increased differentiation of domestic imbalances and local risk factors. In this paper we analyze the evolving nature of bond market integration with the Eurozone bond market, which is proxied by the German market. Our sample includes $16 \mathrm{EU}$ countries, divided into four different groups: (1) Non-EMU new EU (the Czech Republic, Hungary and Poland), (2) non-EMU EU-15 (Denmark, Sweden and UK), (3) EMU EU-15 peripheral (Greece, Ireland, Italy, Portugal and Spain), and (4) EMU EU-15 central bond markets (Austria, Belgium, Finland, France and the Netherlands).

Our sample period begins in 2004, after a period of calm and tranquility in EMU markets, and ends in 2009, with a significant widening of sovereign bond spreads. Our model builds on Bekaert and Harvey (1995)'s CAPM-based model, and we consider that the time-varying coefficient that captures the degree of integration with the Eurozone market is dependent on a set of domestic economic instruments relative to Germany: the inflation differential, the industrial production index rate of growth differential, and the debt-to-GDP rate of growth differential.

We provide empirical evidence for a time-varying level of integration, which decreases in all countries after the beginning of the financial crisis in August 2007. Our results suggest that the relative importance of local factors versus other components in explaining bond returns increases at 
the same time as the downturn in the economic environment in Europe, underlining the imbalances across economies.

The time-series pattern of the degree of integration presents similar trends across our four categories of countries (as expected, the average level of integration with the German market is higher in EMU than in non-EMU countries, and lower in non-EMU new EU countries than in non-EMU EU-15 countries and also in EMU peripheral than in EMU central countries), but the impact of the financial and economic crisis clearly differs between groups and within countries in the same group.

Specifically, after September 2008, the level of integration records average decreases of $42 \%, 28 \%$, $22 \%$ and $9 \%$ in non-EMU EU-15, EMU peripheral, new EU and EMU central countries respectively. Ireland (67\%), Denmark (53\%), the United Kingdom (44\%), Greece (36\%), Poland (34\%), and Sweden and Spain (28\% in both cases) are the countries whose bond markets present the highest drop in the degree of integration with the German one. These results suggest that as the financial and economic crisis deepened, the relevance of local risk factors rose, and that the domestic instruments used to describe the time-varying level of integration (the relative inflation, industrial production and debt-to-GDP growth) seem to be important internal factors that explain the differences in its evolution across countries.

Another important insight that emerges from the results is that the countries with the highest increases in the coefficient of variation of their level of integration with the German market at the end of the period are those that belong to the euro. This is particularly the case of the peripheral countries (with increases of around 178\% since September 2008), suggesting a move towards a higher differentiation of idiosyncratic and local risk factors in these countries after the financial crisis. Conversely, in the case of non-EMU countries the dispersion of the time-varying degree of integration presents a much more stable trend. This suggests that the impact of the financial and economic crisis has been much more harmful for EMU members' sovereign bond markets. 
In fact, following the launch of the euro, Eurozone bond markets achieved a high degree of integration, which was reflected in the stability and convergence of their yield spreads over Germany. However, one of the consequences of the global financial crisis was that it stressed the relevance of domestic imbalances and local risk factors in explaining bond returns, which were probably not accurately priced by agents in euro area markets during the period of stability that preceded it. Consequently, the crisis not only slowed the process of financial integration among EMU bond markets, but also revealed the fragility and weaknesses associated with the conduct of the single monetary policy in Europe. 


\section{References}

1. Abad, P.; H. Chuliá and M. Gómez-Puig (2010). "EMU and UE-15 Government Bond Market Integration". Journal of Banking and Finance, n.34, pp.2851-2860.

2. Afonso, A.; H.D. Grüner and C. Kolerus (2010). "Fiscal Policy and Growth: Do Financial Crises make a difference?". European Central Bank Working Paper Series n. 1217, June.

3. Bekaert, G, and C.R. Harvey (1995). "Time-Varying World Market Integration”. Journal of Finance vol. 1, n.2.

4. Bollerslev, T., R.F. Engle, and J.M. Wooldridge (1988). "A capital asset pricing model with time-varying covariances". Journal of Political Economy No.96, 116-131.

5. Bollerslev, T. and J.M. Wooldridge (1992). "Quasi-Maximum Likelihood Estimation and Inference in Dynamic Models with Time-Varying Covariances". Econometric Review, vol. 11(2), 143-172.

6. Borri, N. and A. Verdelhan (2010). "Sovereign risk premia". American Finance Association 2010 Atlanta Meetings.

7. Campbell, J.Y., and R.J. Shiller (1991). "Yield Spreads and Interest Rate Movements: A Bird's Eye View”. Review of Economic Studies, vol. 58(3), pp. 495-514, May.

8. De Santis, G., and B. Gerard (1997). "International asset pricing and portfolio diversification with time-varying risk" Journal of Finance No.52, 1881-1912.

9. De Santis, G., and B. Gerard (1998). "How big is the premium for currency risk?" Journal of Financial Economics No.49, 375-412.

10. European Central Bank (2010). "Financial Integration in Europe", April.

11. European Commission (2010). "Enhancing economic policy coordination for stability, growth and jobs. Tools for stronger EU economic governance", June.

12. Engle, R.F., and K.F. Kroner (1995). "Multivariate Simultaneous Generalized Arch". Econometric Theory, No.11, 122-150.

13. Fleming, J., Kirby, C., \& Ostdiek, B. (1998). "Information and volatility linkages in the stock, bond and money markets". Journal of Financial Economics, 49, 111-137.

14. Gardó, S. and R. Martin (2010). "The impact of the global economic and financial crisis on central, eastern and south-eastern Europe: A Stock-taking exercise". European Central Bank Occasional Paper Series n. 114, June.

15. Geyer, A., S. Kossmeier and S. Pichler (2004). "Measuring Systematic Risk in EMU Government Yield Spreads". Review of Finance n. 8.

16. Gómez-Puig M. (2009a). "The Immediate Effect of Monetary Union over UE-15’s Sovereign Debt Yield Spreads". Applied Economics, 41, 929-939. 
17. Gómez-Puig, M. (2009b) 'Systemic and Idiosyncratic Risk in UE-15 Sovereign Yield Spreads After Seven Years of Monetary Union”, European Financial Management. Vol. 15, No. 5, $971-$ 1000 .

18. Hardouvelis, G.A., D. Malliaropulos and R. Priestley (2006) "EMU and European Stock Market Integration". Journal of Business, vol. 79, $n^{\circ} 1$.

19. Hunter, D.M., and D.P. Simon (2005). "A Conditional Assessment of the Relationships between the Major World Bond Markets". European Financial Management, Vol. 11, No. 4, 463482

20. Ilmanen, A. (1996). "When do bond markets reward investors for interest rate risk? Journal of Portfolio Management. Winter.

21. Kim, S-J, M. Fariborz and E. Wu (2006). "Evolution of International Stock and Bond Market Integration: Influence of the European Monetary Union". Journal of Banking and Finance, vol. 30, pp. 1507-1534.

22. McQueen, G. and Roley, V. (1993) 'Stock prices, news, and business conditions', Review of Financial Studies, Vol. 6, pp. 683-707.

23. Merton, R.C. (1980). "On estimating the expected return on the market: An exploratory investigation". Journal of Financial Economics 8.

24. Mody, A. (2009). "From Bear Stearns to Anglo Irish: How Eurozone Sovereign Spreads Related to Financial Sector Vulnerability". International Monetary Fund Working Papers 09/108.

25. Nickel, C.; P.C. Rother and J.C. Rülke (2009). "Fiscal variables and bond spreads: Evidence from eastern European countries and Turkey". European Central Bank Working Paper Series $n$. 1101, October.

26. Pagano, M. and E.L. von Thadden. (2004). “The European Bond Markets under EMU”. Oxford Review of Economic Policy, vol. 20, n.4.

27. Reinhart, C. and K.S. Rogoff (2008). "Banking Crises: An Equal Opportunity", NBER Working Paper No. 14587, December.

28. Reinhart, C. and K.S. Rogoff (2010). "Growth in a Time of Debt", American Economic Review, Vol. 100 No. 2, May. 
Table 1. Predicting local excess returns

$r_{i, t}=a_{i}+b{ }_{i} Z^{E}{ }_{t}+b L_{i} Z^{L}{ }_{i, t}+\varepsilon_{i, t}$

\begin{tabular}{|c|c|c|c|c|c|c|c|c|}
\hline & \multirow[b]{2}{*}{$\mathbf{R} 2$} & \multirow[b]{2}{*}{ F-test } & \multirow[b]{2}{*}{$\begin{array}{c}\text { F- test } \\
\text { exclude } \\
\text { Eurozone }\end{array}$} & \multirow[b]{2}{*}{$\begin{array}{c}\text { F- test } \\
\text { exclude } \\
\text { local }\end{array}$} & \multicolumn{2}{|c|}{$\begin{array}{c}\text { Local } \\
\text { instruments only }\end{array}$} & \multicolumn{2}{|c|}{$\begin{array}{c}\text { Eurozone } \\
\text { instruments only }\end{array}$} \\
\hline & & & & & $\mathbf{R} 2$ & F-test & $\mathbf{R} 2$ & F-test \\
\hline Austria & 0.86 & $\begin{array}{c}1201.27 \\
(0.00)\end{array}$ & $\begin{array}{c}249.82 \\
(0.00)\end{array}$ & $\begin{array}{l}15.72 \\
(0.00)\end{array}$ & 0.85 & $\begin{array}{c}2238.53 \\
(0.00)\end{array}$ & 0.64 & $\begin{array}{c}676.08 \\
(0.00)\end{array}$ \\
\hline Belgium & 0.90 & $\begin{array}{c}1653.81 \\
(0.00)\end{array}$ & $\begin{array}{c}150.29 \\
(0.00)\end{array}$ & $\begin{array}{c}6.70 \\
(0.00)\end{array}$ & 0.89 & $\begin{array}{c}3187.32 \\
(0.00)\end{array}$ & 0.68 & $\begin{array}{c}822.45 \\
(0.00)\end{array}$ \\
\hline Czech Republic & 0.78 & $\begin{array}{c}588.38 \\
(0.00)\end{array}$ & $\begin{array}{l}146.03 \\
(0.00)\end{array}$ & $\begin{array}{l}26.13 \\
(0.00)\end{array}$ & 0.73 & $\begin{array}{l}909.25 \\
(0.00)\end{array}$ & 0.04 & $\begin{array}{l}13.62 \\
(0.00)\end{array}$ \\
\hline Denmark & 0.87 & $\begin{array}{c}1292.72 \\
(0.00)\end{array}$ & $\begin{array}{l}203.02 \\
(0.00)\end{array}$ & $\begin{array}{l}13.45 \\
(0.00)\end{array}$ & 0.86 & $\begin{array}{c}2421.78 \\
(0.00)\end{array}$ & 0.55 & $\begin{array}{l}472.68 \\
(0.00)\end{array}$ \\
\hline Finland & 0.35 & $\begin{array}{l}102.47 \\
(0.00)\end{array}$ & $\begin{array}{l}53.07 \\
(0.00)\end{array}$ & $\begin{array}{c}3.49 \\
(0.01)\end{array}$ & 0.28 & $\begin{array}{l}145.78 \\
(0.00)\end{array}$ & 0.09 & $\begin{array}{l}35.91 \\
(0.00)\end{array}$ \\
\hline France & 0.91 & $\begin{array}{c}1943.85 \\
(0.00)\end{array}$ & $\begin{array}{l}927.93 \\
(0.00)\end{array}$ & $\begin{array}{l}1.52^{*} \\
(0.19)\end{array}$ & 0.91 & $\begin{array}{c}3886.74 \\
(0.00)\end{array}$ & 0.69 & $\begin{array}{l}874.98 \\
(0.00)\end{array}$ \\
\hline Greece & 0.87 & $\begin{array}{c}1270.78 \\
(0.00)\end{array}$ & $\begin{array}{l}262.54 \\
(0.00)\end{array}$ & $\begin{array}{l}10.13 \\
(0.00)\end{array}$ & 0.86 & $\begin{array}{c}2354.36 \\
(0.00)\end{array}$ & 0.46 & $\begin{array}{c}323.63 \\
(0.00)\end{array}$ \\
\hline Hungary & 0.56 & $\begin{array}{c}212.65 \\
(0.00)\end{array}$ & $\begin{array}{c}133.30 \\
(0.00)\end{array}$ & $\begin{array}{l}0.39 * \\
(0.82)\end{array}$ & 0.56 & $\begin{array}{c}422.11 \\
(0.00)\end{array}$ & 0.01 & $\begin{array}{c}3.42 \\
(0.01)\end{array}$ \\
\hline Ireland & 0.81 & $\begin{array}{l}829.47 \\
(0.00)\end{array}$ & $\begin{array}{l}92.42 \\
(0.00)\end{array}$ & $\begin{array}{l}14.29 \\
(0.00)\end{array}$ & 0.78 & $\begin{array}{c}1356.42 \\
(0.00)\end{array}$ & 0.41 & $\begin{array}{c}269.58 \\
(0.00)\end{array}$ \\
\hline Italy & 0.88 & $\begin{array}{c}1390.23 \\
(0.00)\end{array}$ & $\begin{array}{l}190.60 \\
(0.00)\end{array}$ & $\begin{array}{c}4.40 \\
(0.00)\end{array}$ & 0.88 & $\begin{array}{c}2710.95 \\
(0.00)\end{array}$ & 0.57 & $\begin{array}{l}504.68 \\
(0.00)\end{array}$ \\
\hline Netherlands & 0.90 & $\begin{array}{c}1822.68 \\
(0.00)\end{array}$ & $\begin{array}{c}618.39 \\
(0.00)\end{array}$ & $\begin{array}{c}2.14 \\
(0.07)\end{array}$ & 0.90 & $\begin{array}{c}3620.25 \\
(0.00)\end{array}$ & 0.70 & $\begin{array}{c}878.34 \\
(0.00)\end{array}$ \\
\hline Poland & 0.54 & $\begin{array}{c}221.24 \\
(0.00)\end{array}$ & $\begin{array}{l}48.92 \\
(0.00)\end{array}$ & $\begin{array}{l}53.79 \\
(0.00)\end{array}$ & 0.37 & $\begin{array}{c}228.80 \\
(0.00)\end{array}$ & 0.16 & $\begin{array}{l}72.35 \\
(0.00)\end{array}$ \\
\hline Portugal & 0.86 & $\begin{array}{c}1145.85 \\
(0.00)\end{array}$ & $\begin{array}{l}92.79 \\
(0.00)\end{array}$ & $\begin{array}{l}11.38 \\
(0.00)\end{array}$ & 0.83 & $\begin{array}{c}1936.31 \\
(0.00)\end{array}$ & 0.56 & $\begin{array}{c}482.10 \\
(0.00)\end{array}$ \\
\hline Spain & 0.91 & $\begin{array}{c}1988.94 \\
(0.00)\end{array}$ & $\begin{array}{l}97.66 \\
(0.00)\end{array}$ & $\begin{array}{c}4.75 \\
(0.00)\end{array}$ & 0.91 & $\begin{array}{c}3829.03 \\
(0.00)\end{array}$ & 0.67 & $\begin{array}{c}764.89 \\
(0.00)\end{array}$ \\
\hline Sweden & 0.49 & $\begin{array}{c}181.35 \\
(0.00)\end{array}$ & $\begin{array}{l}79.40 \\
(0.00)\end{array}$ & $\begin{array}{l}14.15 \\
(0.00)\end{array}$ & 0.37 & $\begin{array}{c}222.59 \\
(0.00)\end{array}$ & 0.14 & $\begin{array}{l}64.10 \\
(0.00)\end{array}$ \\
\hline U.K. & 0.72 & $\begin{array}{c}504.52 \\
(0.00)\end{array}$ & $\begin{array}{c}366.27 \\
(0.00)\end{array}$ & $\begin{array}{l}38.41 \\
(0.00)\end{array}$ & 0.59 & $\begin{array}{c}558.26 \\
(0.00)\end{array}$ & 0.19 & $\begin{array}{l}89.16 \\
(0.00)\end{array}$ \\
\hline
\end{tabular}

Note: : The sample period goes from 5 January, 2004 to 30 November, 2009, except for the Czech Republic and Hungary whose start date is 1 November, 2004. This table reports OLS estimations of the equation. R2 denote R-squared statistic. F-test denotes the F-statistic from a test of the hypothesis that all of the slope coefficients (excluding the intercept) in the regression are zero. "F-test exclude X" denotes the F-statistic from a test of the hypothesis that some coefficients (all excluding the set $\mathrm{X}$ ) in the regression are zero. P-values are displayed in parentheses. 
Table 2. Model estimates for each of the local Government bond market jointly with the Eurozone Government bond market $r_{i, t}=\theta_{i, t} \lambda_{e, t} \operatorname{cov}_{t-1}\left(\mathrm{r}_{e, t,} \mathrm{r}_{i, t}\right)+\left(1-\theta_{i, t}\right) \lambda_{i, t} \operatorname{var}_{t-1}\left(\mathrm{r}_{i, t}\right)+e_{i, t}$

$$
\begin{gathered}
r_{\mathrm{E}, t}=\lambda_{\mathrm{E}, t} \operatorname{var}\left(\mathrm{r}_{\mathrm{E}, t}\right)+e_{\mathrm{E}, t} \\
\theta_{i, t}=\exp \left(-\left|g_{i}^{\prime} X_{i, t}\right|\right), \lambda_{E, t}=\exp \left(\mathrm{K}_{\mathrm{E}}^{\prime} \mathrm{Z}_{t}\right), \lambda_{i, t}=\exp \left(\delta_{\mathrm{L}}^{\prime} \mathrm{Z}_{i, t}\right) \\
\mathbf{H}_{t}=\mathbf{C}^{\prime} \mathbf{C}+\mathbf{A}^{\prime} \boldsymbol{e}_{t-1} \boldsymbol{e}_{t-1}^{\prime} \mathbf{A}+\mathbf{B}^{\prime} \mathbf{H}_{t-1} \mathbf{B}
\end{gathered}
$$

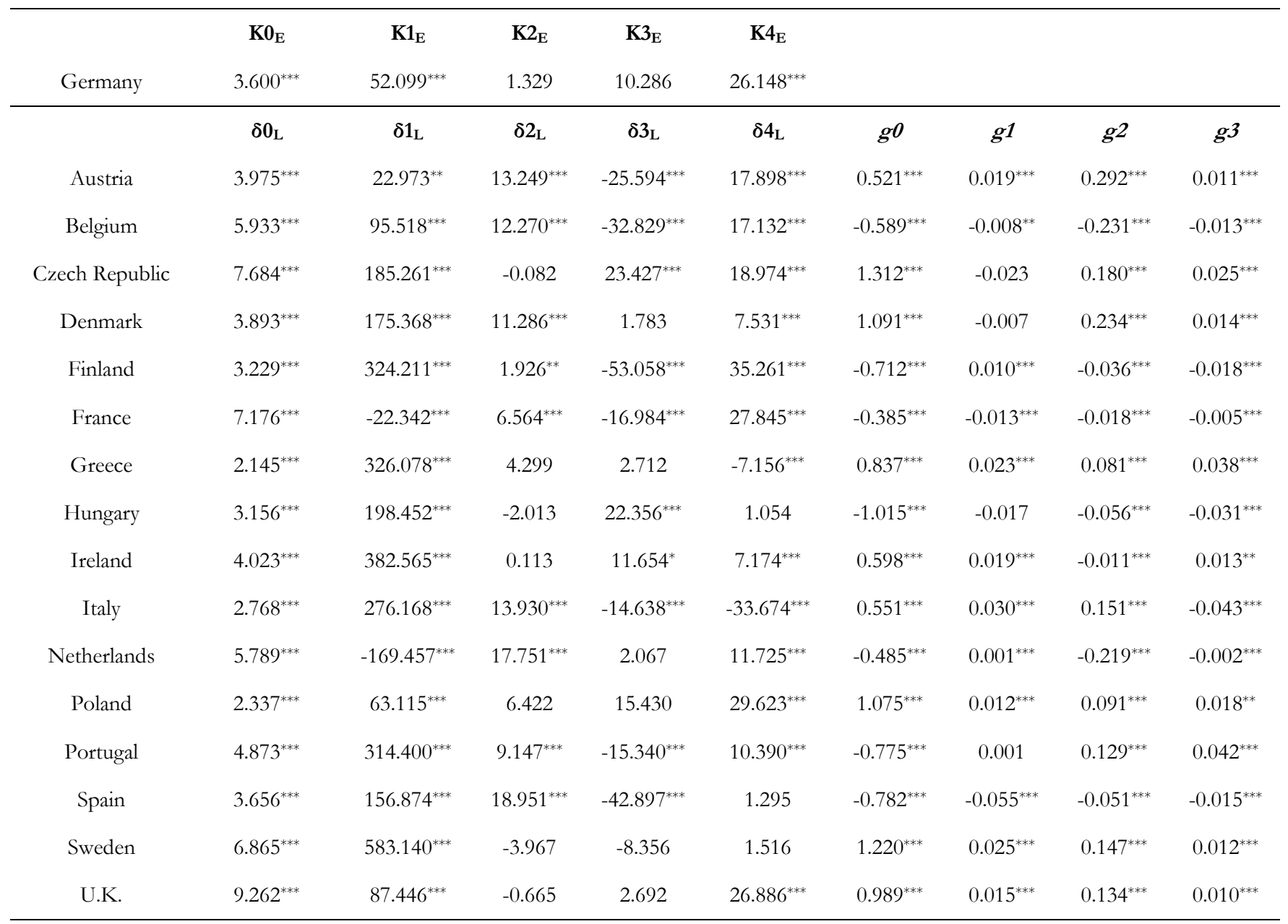

Note: : The sample period goes from 5 January, 2004 to 30 November, 2009, except for the Czech Republic and Hungary whose start date is 1 November, 2004. We estimate a system of equations [(1) to (6)] using the Maximum Likelihood method for each of the local Government bond markets jointly with the Eurozone bond market. Note: The superscripts ${ }^{* * *},{ }^{* *}$ and ${ }^{*}$ indicate statistical significance at the $1 \%, 5 \%$ and $10 \%$ levels respectively. 
Table 3. Summary statistics for the standardized residuals of the model estimates for each of the local Government bond markets jointly with the Eurozone (Germany) Government bond market

\begin{tabular}{|c|c|c|c|}
\hline & $\begin{array}{c}\text { Maximum } \\
\text { likelihood } \\
\text { function } \\
\text { value }\end{array}$ & $Q(20)$ & $\mathrm{ARCH}(20)$ \\
\hline Germany & & $\begin{array}{l}30.784 \\
(0.05)\end{array}$ & $\begin{array}{l}3.603 \\
(0.99)\end{array}$ \\
\hline Austria & 14228.899 & $\begin{array}{c}19.339 \\
(0.49)\end{array}$ & $\begin{array}{l}1.350 \\
(0.99)\end{array}$ \\
\hline Belgium & 14591.622 & $\begin{array}{c}24.859 \\
(0.21)\end{array}$ & $\begin{array}{l}3.938 \\
(0.99)\end{array}$ \\
\hline $\begin{array}{l}\text { Czech } \\
\text { Republic }\end{array}$ & 9981.915 & $\begin{array}{c}23.159 \\
(0.28)\end{array}$ & $\begin{array}{l}1.064 \\
(0.99)\end{array}$ \\
\hline Denmark & 13817.149 & $\begin{array}{l}19.486 \\
(0.49)\end{array}$ & $\begin{array}{l}3.511 \\
(0.99)\end{array}$ \\
\hline Finland & 13691.701 & $\begin{array}{c}22.930 \\
(0.29)\end{array}$ & $\begin{array}{l}1.975 \\
(0.99)\end{array}$ \\
\hline France & 15230.485 & $\begin{array}{c}26.798 \\
(0.14)\end{array}$ & $\begin{array}{l}3.752 \\
(0.99)\end{array}$ \\
\hline Greece & 13402.859 & $\begin{array}{c}22.111 \\
(0.33)\end{array}$ & $\begin{array}{l}2.700 \\
(0.99)\end{array}$ \\
\hline Hungary & 9337.573 & $\begin{array}{c}28.004 \\
(0.10)\end{array}$ & $\begin{array}{c}43.076 \\
(0.00)\end{array}$ \\
\hline Ireland & 13499.308 & $\begin{array}{c}19.712 \\
(0.47)\end{array}$ & $\begin{array}{l}2.700 \\
(0.99)\end{array}$ \\
\hline Italy & 13594.454 & $\begin{array}{l}20.550 \\
(0.42)\end{array}$ & $\begin{array}{l}1.304 \\
(0.99)\end{array}$ \\
\hline Netherlands & 15343.510 & $\begin{array}{l}26.112 \\
(0.16)\end{array}$ & $\begin{array}{l}7.557 \\
(0.88)\end{array}$ \\
\hline Poland & 11175.189 & $\begin{array}{l}35.775 \\
(0.02)\end{array}$ & $\begin{array}{c}13.002 \\
(0.99)\end{array}$ \\
\hline Portugal & 13457.336 & $\begin{array}{c}17.511 \\
(0.61)\end{array}$ & $\begin{array}{l}2.930 \\
(0.99)\end{array}$ \\
\hline Spain & 14331.815 & $\begin{array}{c}26.511 \\
(0.15)\end{array}$ & $\begin{array}{l}7.463 \\
(0.99)\end{array}$ \\
\hline Sweden & 12249.642 & $\begin{array}{l}18.475 \\
(0.55)\end{array}$ & $\begin{array}{c}2.922 \\
(0.099)\end{array}$ \\
\hline U.K. & 11808.142 & $\begin{array}{l}27.355 \\
(0.12)\end{array}$ & $\begin{array}{l}2.026 \\
(0.99)\end{array}$ \\
\hline
\end{tabular}

Note: $\mathrm{Q}(20)$ is the Ljung-Box test for twentieth order serial correlation in the standardized residuals. ARCH(20) is Engle's test for twentieth order ARCH, distributed as chi-square distribution with 20 degrees of freedom.. The p-values of these tests are displayed in parentheses. In all cases the necessary conditions for the stationarity of the process are satisfied. 
Table 4. Average level of the time-varying degree of integration

\begin{tabular}{lcccc}
\hline & $\mathbf{0 5 / 0 1 / 2 0 0 4 -}$ & $\mathbf{0 9 / 0 8 / 2 0 0 7 -}$ & $\mathbf{1 5 / 0 9 / 2 0 0 8 -}$ & Total period \\
\hline Austria & 0.548 & $\mathbf{3 0 / 1 1 / 2 0 0 9}$ & 0.540 \\
Belgium & 0.579 & 0.547 & 0.513 & 0.547 \\
Czech Republic & 0.312 & 0.477 & 0.515 & 0.254 \\
Denmark & 0.436 & 0.160 & 0.210 & 0.374 \\
Finland & 0.573 & 0.367 & 0.195 & 0.538 \\
France & 0.716 & 0.558 & 0.419 & 0.698 \\
Greece & 0.467 & 0.699 & 0.643 & 0.422 \\
Hungary & 0.316 & 0.418 & 0.293 & 0.234 \\
Ireland & 0.640 & 0.262 & 0.270 & 0.515 \\
Italy & 0.555 & 0.459 & 0.196 & 0.579 \\
Netherlands & 0.670 & 0.676 & 0.561 & 0.656 \\
Poland & 0.315 & 0.774 & 0.509 & 0.296 \\
Portugal & 0.540 & 0.326 & 0.211 & 0.523 \\
Spain & 0.550 & 0.484 & 0.506 & 0.544 \\
Sweden & 0.365 & 0.663 & 0.416 & 0.343 \\
U.K. & 0.384 & 0.361 & 0.263 & 0.350 \\
\hline
\end{tabular}

Note: This table shows the average level of integration for the total sample period and three sub-sample periods: (1) From 4 January 2004 to 8 August 2007, (2) from the beginning of the subprime crisis on 9 August 2007 to 14 September 2008 and (3) from the collapse of Lehman Brothers on 15 September 2008 to 30 November 2009. : The total period goes from 5 January, 2004 to 30 November, 2009, except for the Czech Republic and Hungary whose start date is 1 November, 2004. 
Table 5. Average level of the coefficient of variation of the time-varying degree of integration

\begin{tabular}{lcccc}
\hline & $\mathbf{0 5 / 0 1 / 2 0 0 4 -}$ & $\mathbf{0 9 / 0 8 / 2 0 0 7 -}$ & $\mathbf{1 5 / 0 9 / 2 0 0 8 -}$ & \\
& $\mathbf{0 8 / 0 8 / 2 0 0 7}$ & $\mathbf{1 4 / 0 9 / 2 0 0 8}$ & $\mathbf{3 0 / 1 1 / 2 0 0 9}$ & Total period \\
\hline New EU countries (Fig. 2a) & 14.93 & 35.17 & 15.81 & 19.51 \\
Non-EMU EU-15 countries (Fig. 2b) & 10.01 & 9.36 & 17.73 & 11.47 \\
Peripheral EMU EU-15 countries (Fig. 2c) & 15.59 & 24.89 & 43.35 & 23.01 \\
Central EMU EU-15 countries (Fig. 2d) & 13.72 & 22.79 & 21.39 & 16.98 \\
\hline
\end{tabular}

Note: This table shows the average of the daily coefficient of variation [(Standard Deviation / Mean) x 100] for the four groups of countries which correspond to figures $2 \mathrm{a}-2 \mathrm{~d}$. The coefficient of variation is a measure of variability that provides a unitless measure of the variation by translating it into a percentage of the mean value. This measure can be used when comparing two samples that have different means and standard deviations. The total period goes from 5 January, 2004 to 30 November, 2009, except for theCzech Republic and Hungary whose start date is 1 November, 2004 
Figure 1. EMU EU-15 10 year yield spreads over Germany (1999-2009)

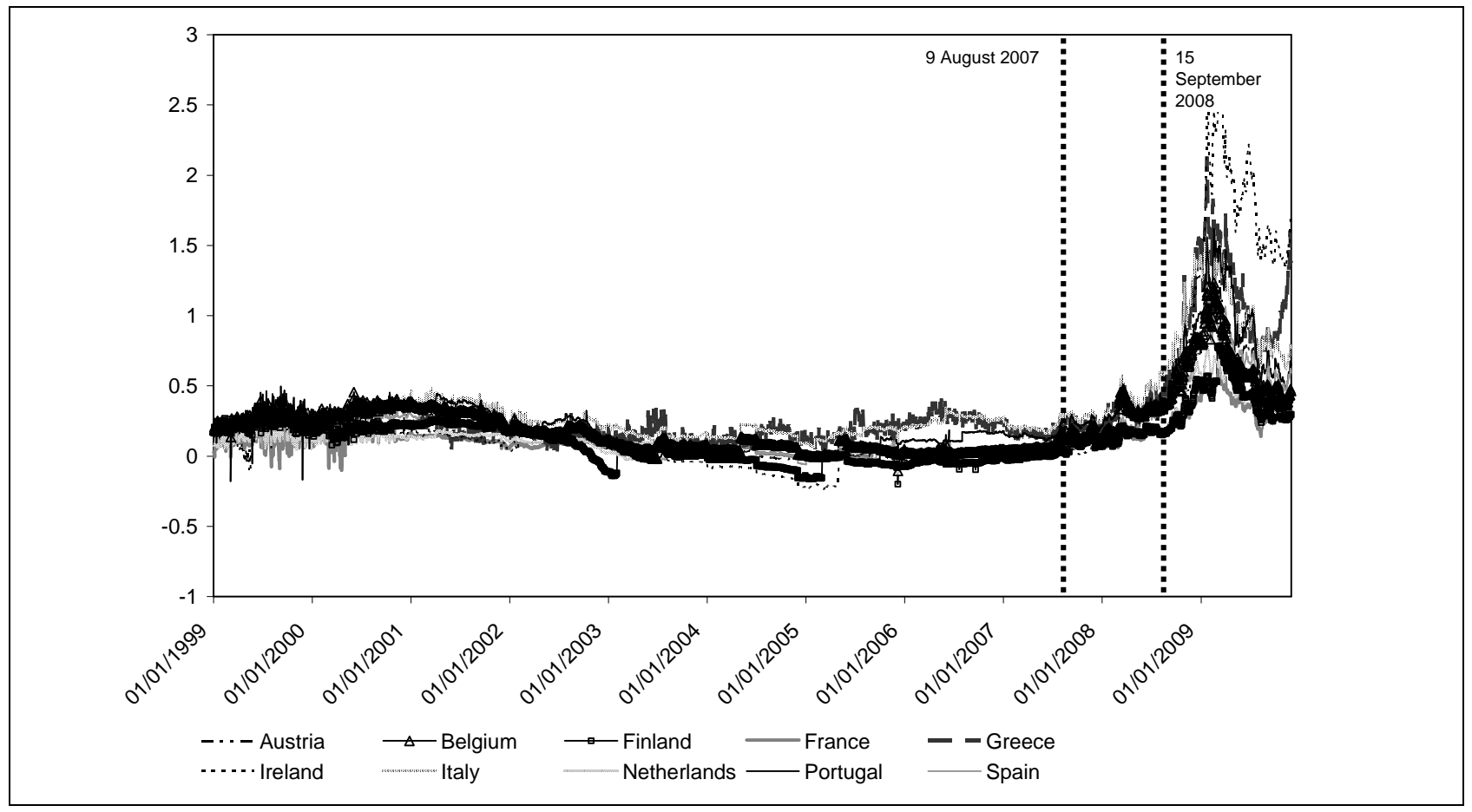


Figure 2. Estimates of the conditional level of integration of market $i$ with the German bond market $\left(\theta_{i, t-1}\right)$

Figure 2a. New EU countries

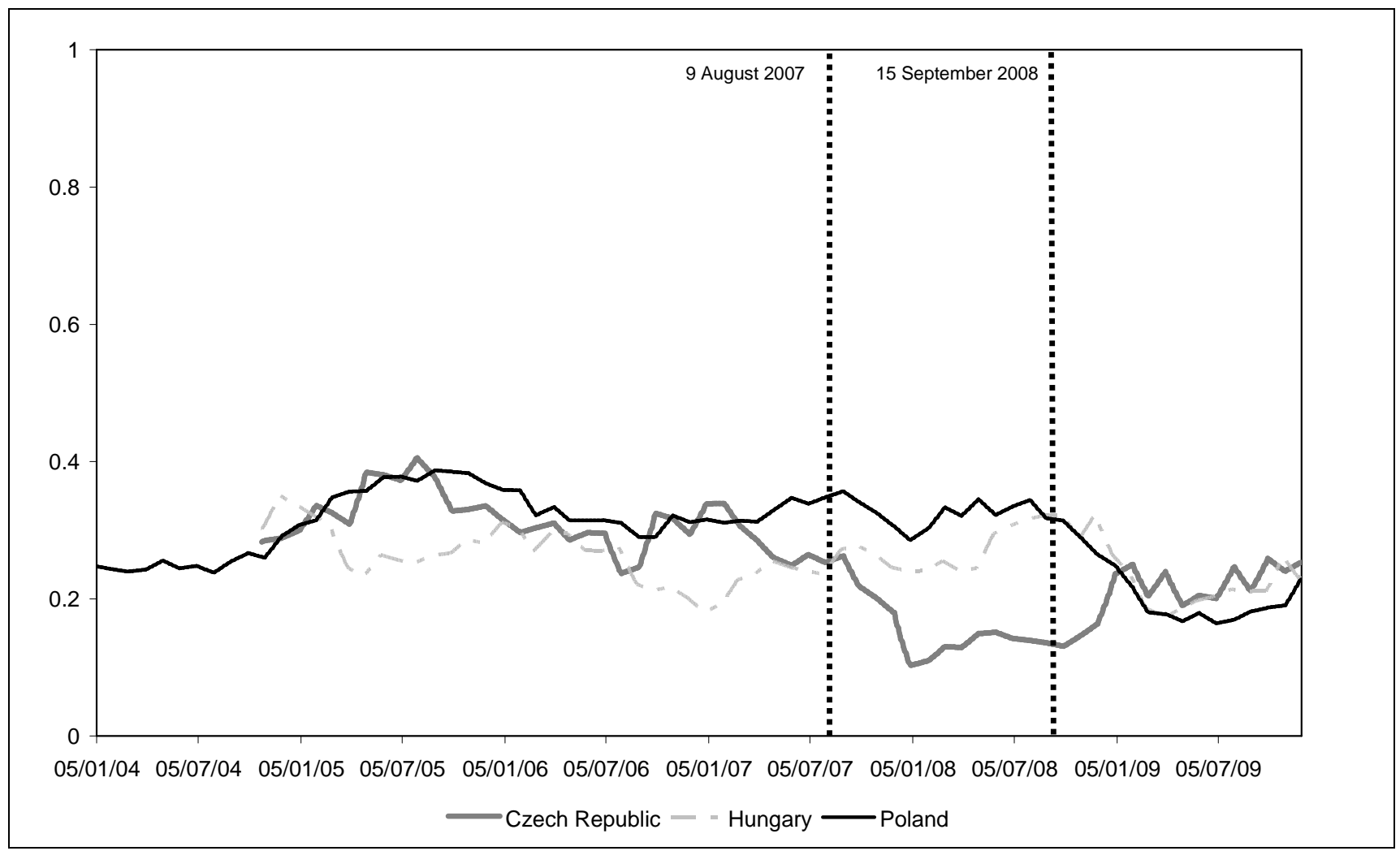

Figure 2b. Non-EMU EU-15 countries

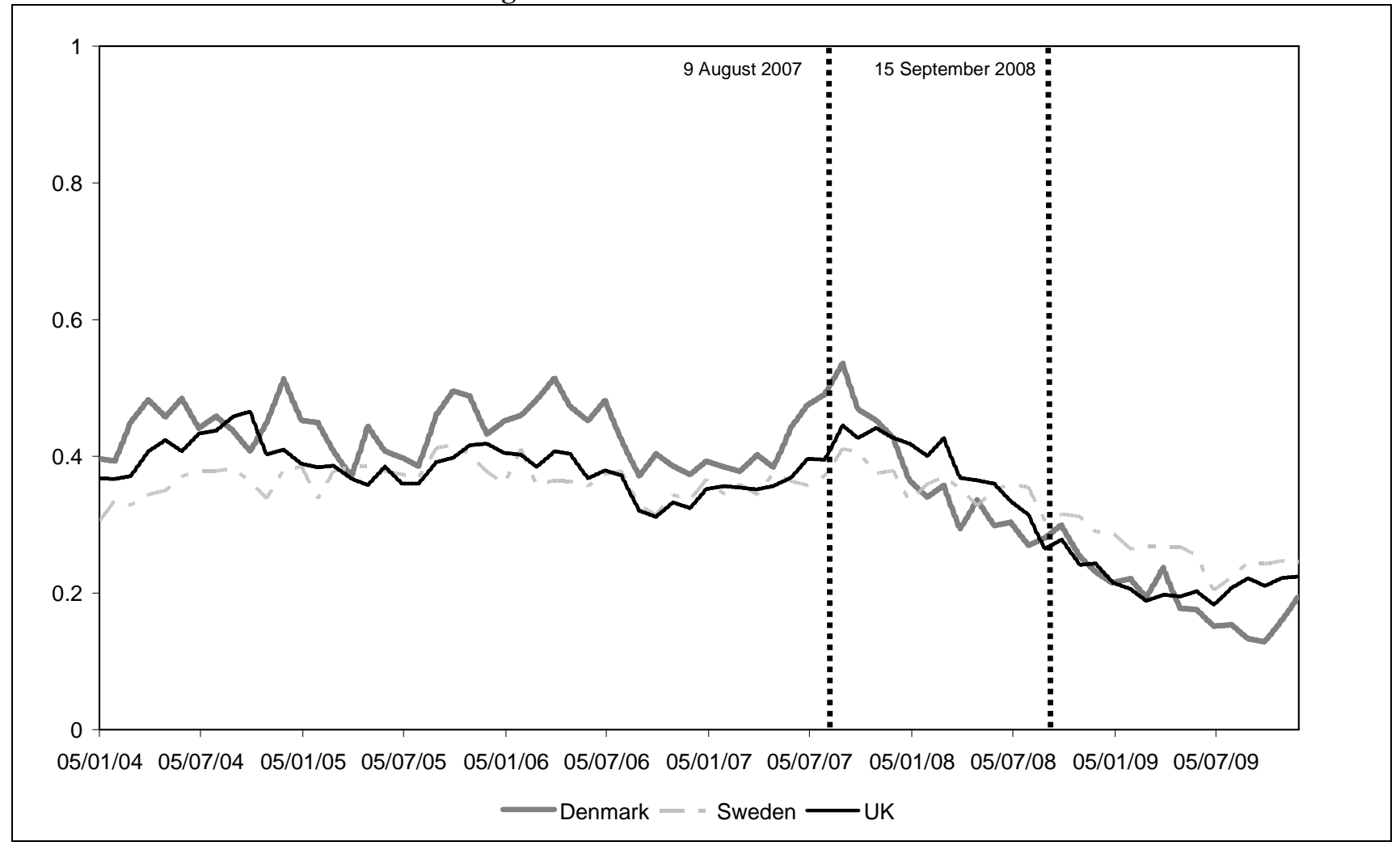


Figure 2c. Peripheral EMU EU-15 countries

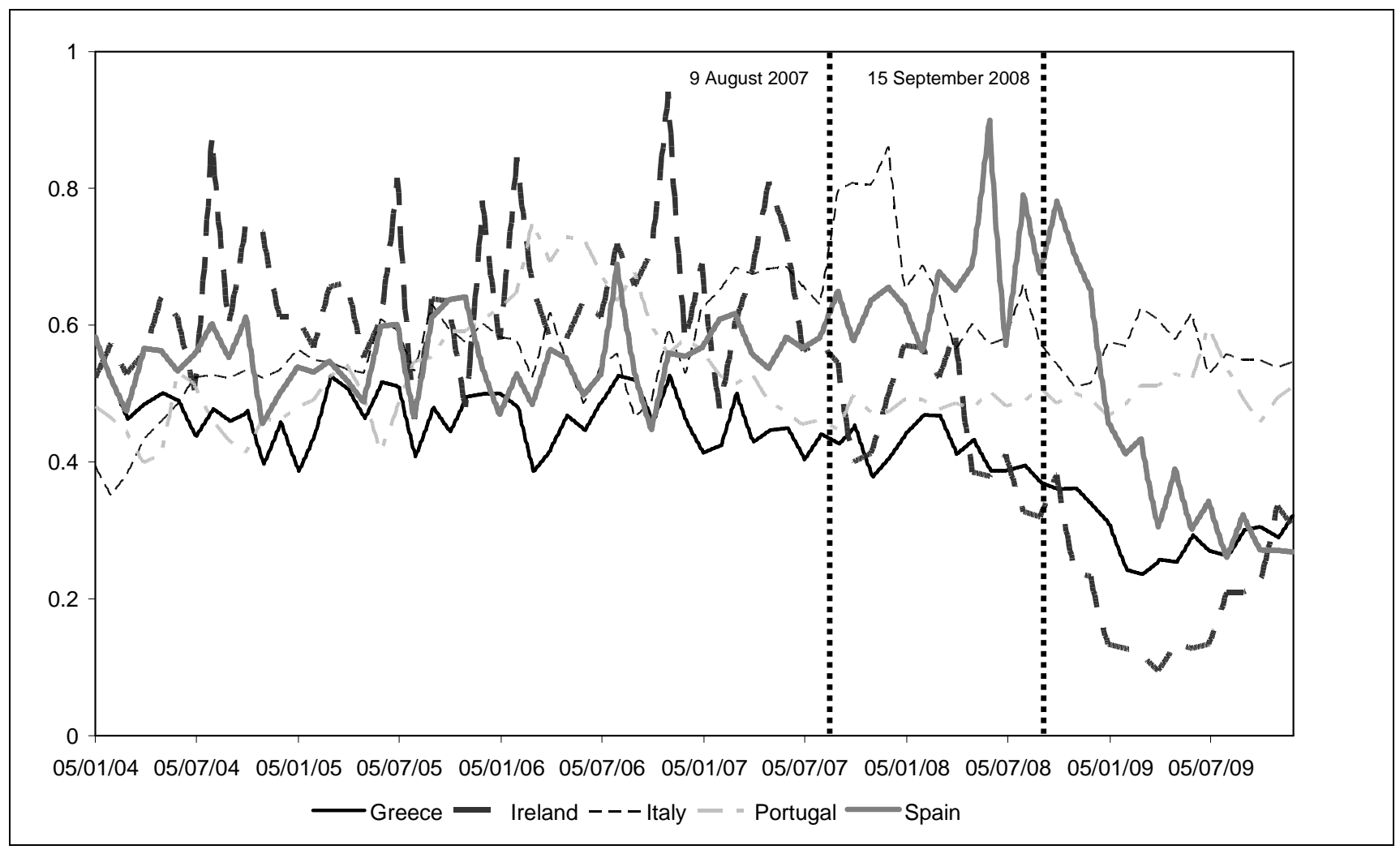

Figure 2d. Central EMU EU-15 countries

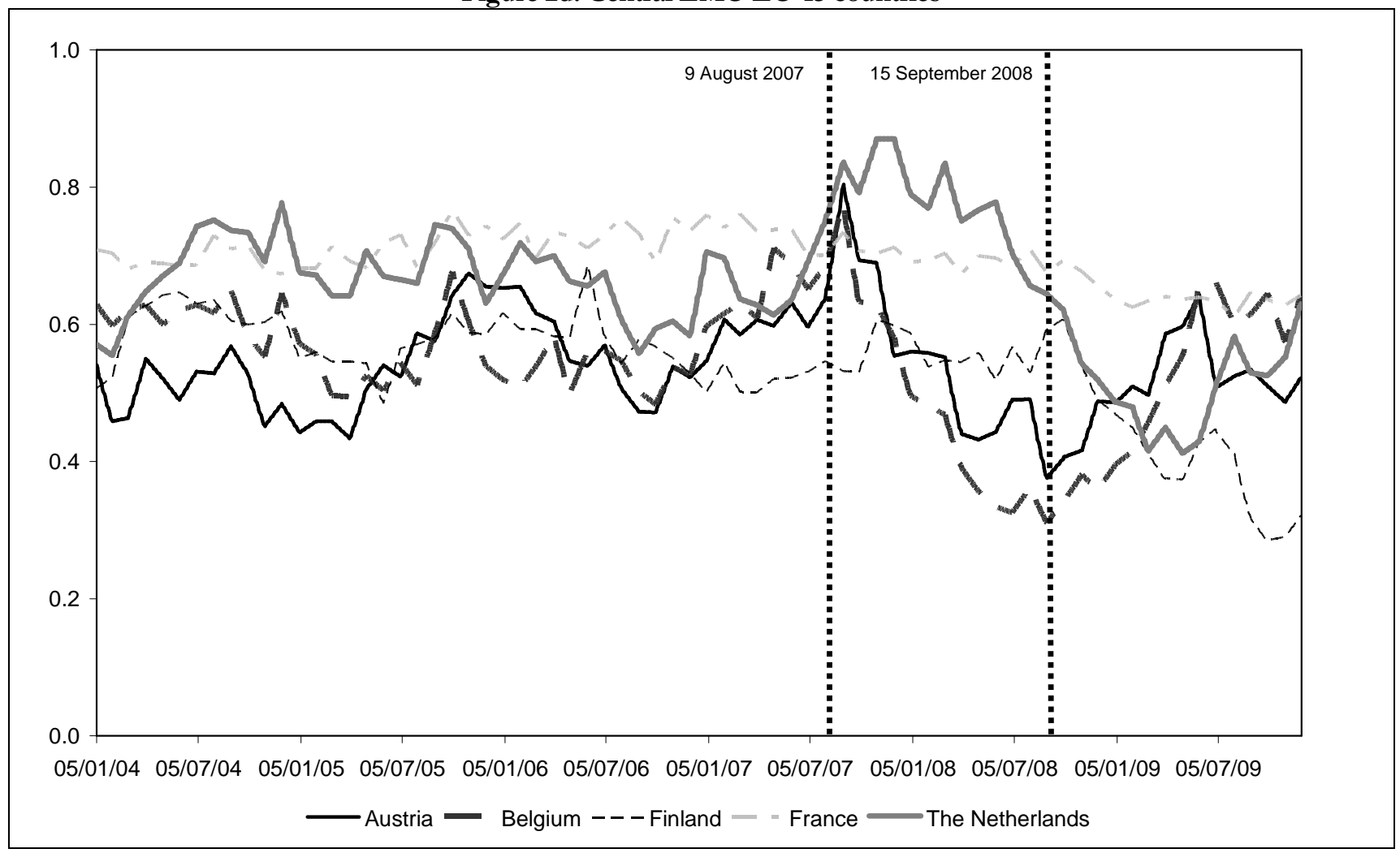

